Published in final edited form as:

J Org Chem. 2005 August 19; 70(17): 6842-6847.

\title{
Complete Stereochemistry of Neamphamide A and Absolute Configuration of the $\beta$-Methoxytyrosine Residue in Papuamide B
}

\author{
Naoya Oku $\dagger$, Ravi Krishnamoorthy $\ddagger$, Alan G. Benson $\ddagger$, Robert L. Ferguson $\ddagger$, Mark A. \\ Lipton $\ddagger$, Lawrence R. Phillips $\S$, Kirk R. Gustafson ${ }^{\star}, \dagger$, and James B. McMahon ${ }^{\dagger}$ \\ † Molecular Targets Development Program, CCR, NCI. Molecular Targets Development Program, \\ Center for Cancer Research, National Cancer Institute, Building 1052, Room 121, Frederick, \\ Maryland 21702-1201
}

$\ddagger$ Purdue University. Department of Chemistry, Purdue University, West Lafayette, Indiana 47907-2084

$\S$ Biological Testing Branch, DTP, NCl. Biological Testing Branch, Developmental Therapeutics Program, National Cancer Institute, Building 1047, Room 5, Frederick, MD 21701-1201

\begin{abstract}
The absolute stereochemistry of the three unresolved structural components in neamphamide A (1) was determined to be $(R)$ - $\beta$-methoxy-L-tyrosine, $(2 R, 3 R, 4 S)$-4-amino-7-guanidino-2,3dihydroxyheptanoic acid, and $(2 R, 3 R, 4 R)$-3-hydroxy-2,4,6-trimethylheptanoic acid. Stereochemical assignments were made by chemical degradation of $\mathbf{1}$, derivatization of the resulting products, and then spectroscopic and chromatographic comparison of the derivatives with synthetically prepared standards. Using the same analytical protocol developed for $\mathbf{1}$, the $\beta$-methoxytyrosine residue in papuamide B (2) was found to be $(R)-\beta$-methoxy-D-tyrosine. This represents a rare example of divergent stereochemistry in an unusual amino acid residue that is present in two closely related classes of peptides.
\end{abstract}

\section{Introduction}

A series of potent HIV inhibitory cyclic depsipeptides have recently been described from a number of marine sponges. Peptides in this family include neamphamide A (1) from Neamphius huxleyi, ${ }^{1}$ the callipeltins from Callipelta $\mathrm{sp.},{ }^{2}$ and the papuamides from Theonella sponges. ${ }^{3}$ In addition to antiviral activity, these compounds have been reported to exhibit potent antifungal, cytotoxic, and sodium ionophore properties. ${ }^{4}$ Distinguishing structural characteristics of this family of peptides include a preponderance of unusual amino acid residues and unique $\mathrm{N}$-terminal polyketide derived moieties. The novel structural features and diverse biological effects of these peptidic metabolites have generated considerable interest among synthetic chemistry groups. As a result, syntheses of structural subunits such as 3,4dimethylglutamine (3,4-diMeGln), 5 4-amido-7-guanidino-2,3-dihydroxyheptanoic acid (3, Agdha), 6 -and 3-hydroxy-2,4,6-trimethylheptanoic acid (4, Htmha ${ }^{7}$ have been described. These efforts provided essential building blocks for use in total synthesis of the parent peptides and they also helped to unambiguously define the absolute stereochemistry of several key chiral centers. However, synthetic efforts to prepare the intact natural products have been hampered by unresolved questions concerning the stereochemistry of the $\beta$-methoxytyrosine (5,

\footnotetext{
* To whom correspondence should be addressed. Tel: (301)-846-5391. Fax: (301)-846-6919.

Supporting Information Available. Experimental procedures, ${ }^{1} \mathrm{H}$ NMR spectra of $\mathbf{3}$ at $0 \mathrm{~h}$ and $24 \mathrm{~h}$ in $\mathrm{CD}_{3} \mathrm{OD}$, positive ESI-MS spectra of 3 obtained before and after $60 \mathrm{~h}-\mathrm{NMR}$ experiments, ${ }^{1} \mathrm{H}$ NMR, gHSQC, and $1 \mathrm{D}$ gNOESY spectra of 7 in CD $3 \mathrm{OD},{ }^{1} \mathrm{H}$ NMR, gHSQC, and $1 \mathrm{D}$ gNOESY spectra of $\mathbf{8}$ in $\mathrm{D}_{2} \mathrm{O},{ }^{1} \mathrm{H}$ NMR and gHSQC spectra of $\mathbf{4}$ from $\mathbf{1}$ and synthetic $(2 R, 3 R, 4 R)-\mathbf{4}$, GC-MS analysis of 16 derived from $\mathbf{1}$ and $\mathbf{2}$.
} 
$\beta O M e T y r)$ residues which occur throughout this family of peptides. While stereoselective syntheses of all four diastereomers of $\mathbf{5}$ has been reported, ${ }^{8}$ the absolute stereochemistry of this residue in the natural peptides was never established. Decomposition of $\mathbf{5}$ during acid hydrolysis of the parent peptide prevented the successful application of standard techniques such as Marfey's analysis. ${ }^{9}$ In the original report of neamphamide A (1), the chirality of the Agdha, Htmha and $\beta O M e T y r$ residues was left undefined. Described herein is the first complete stereochemical assignment of neamphamide A (1) and a general method for determining the absolute stereochemistry of $\beta O M e T y r(5)$ residues in other peptides. This technique was also used to unambiguously define the stereochemistry of the same residue in papuamide B (2), and the results of these analyses should help focus the synthetic efforts underway to prepare the parent peptides.

\section{Results and Discussion}

Our prior studies had established the absolute stereochemistry of 9 amino acid residues of neamphamide A (1) as D-Arg, L-Leu, D- and L-Asn, L- $N$ MeGln, L-homoproline, D-allo-Thr (two residues), and (3S,4R)-3,4-diMe-L-Gln. In addition, C4 of the Agdha (3) moiety was assigned a $S$-configuration by chemical degradation involving diol-cleavage, oxidative work up, and acid hydrolysis, followed by Marfey's analysis of the resulting arginine subunit. ${ }^{1}$ In the current study, a synthetic standard of $\mathbf{3}$ with defined stereochemistry was available for comparative purposes, ${ }^{6}$ but direct application of Marfey's method to the peptide hydrolysate to determine the stereochemistry at $\mathrm{C} 2$ and $\mathrm{C} 3$ proved unsuitable. The L-FDAA derivative of 3 had poor retention on reversed-phase chromatography packings and unacceptable peak broadening in the LC-MS analysis. Accordingly, the $\gamma$-amino acid $\mathbf{3}$ was isolated from the hydrolysate of $\mathbf{1}$ and converted into cyclic derivatives appropriate for NMR based configurational analysis at $\mathrm{C} 2, \mathrm{C} 3$, and $\mathrm{C} 4$. Compound $\mathbf{1}$ was hydrolyzed in $6 \mathrm{~N} \mathrm{HCl}\left(107^{\circ} \mathrm{C}\right.$, $18.5 \mathrm{~h}$ ), defatted with EtOAc, and the resulting aqueous hydrolysate was purified by anionand then cation-exchange chromatography to give a mixture of $\mathbf{3}$ and Arg. While dissolved in $\mathrm{CD}_{3} \mathrm{OD}$ for NMR studies, compound $\mathbf{3}$ was gradually converted to the trideuteriomethyl ester derivative 6. This transformation was evidenced from ${ }^{1} \mathrm{H}$ resonances at $\delta 4.03(\mathrm{H} 3$ of 3 ) and $4.37(\mathrm{H} 2$ of 3 ), which diminished in intensity while resonances at $\delta 4.03$ (H3 of $\mathbf{6})$ and 4.35 (H4 of 6) emerged and grew with time (Supporting Information). Positive ion ESI-MS data obtained before and after the NMR experiments showed the appearance of a dominant ion peak at $\mathrm{m} / \mathrm{z} 252^{10}$ and complete loss of the original peak at $\mathrm{m} / \mathrm{z} 235$ (Supporting Information), which supported the conversion of $\mathbf{3}$ to the methyl ester $\mathbf{6}$. Preparation of the acetonide of $\mathbf{6}$ with 2,2dimethoxypropane and PPTS in DMF exclusively yielded the 2,3- $O, O$-isopropylidene derivative 7. ${ }^{11}$ In $1 \mathrm{D}$ gNOESY experiments, selective irradiation of one of the acetonide methyl signals at $\delta 1.36$ excited the two oxymethine protons at $\delta 4.65(\mathrm{H} 2)$ and $\delta 4.74(\mathrm{H} 3)$. No NOE enhancement was observed with these protons upon irradiation of the other methyl group at $\delta 1.40$, thus indicating $\mathrm{H} 2$ and $\mathrm{H} 3$ were on the same face of the dioxolane ring. To correlate the erythro-diol moiety at C2-C3 with the $S$-configuration of neighboring C4, 7 was treated with $2 \mathrm{~N} \mathrm{HCl}$ to recover 3 , which was then refluxed in $\mathrm{H}_{2} \mathrm{O}$ for $60 \mathrm{~h}$ to achieve partial conversion into Agdha $\gamma$-lactam $\left(\mathbf{8}, 63 \%\right.$ yield). ${ }^{12}$ The coupling constants observed between protons on the lactam ring of 8 were $J_{\mathrm{H} 2, \mathrm{H} 3}=4.7-4.9 \mathrm{~Hz}$ and $J_{\mathrm{H} 3, \mathrm{H} 4}=3.6 \mathrm{~Hz}$. This combination of couplings was compared to the reported values for four similarly functionalized synthetic $\gamma$-lactams (Scheme 1), 13 and they were only compatible with the $(2 R, 3 R, 4 S)$-isomer. Further support for this stereochemical assignment was provided by mutual NOE interactions between $\mathrm{H} 2(\delta 4.31)$ and $\mathrm{H} 4(\delta 3.52)$ in a $1 \mathrm{D}$ gNOESY experiment. Thus, the configuration of $\mathbf{3}$ in the peptide 1 was determined to be $(2 R, 3 R, 4 S)$, which is consistent with the stereochemistry previously assigned to the Agdha residue in callipeltin A (9). ${ }^{2}$

The EtOAc extract of the acid hydrolysate of neamphamide A (1) contained free Htmha (4) as the major constituent. Careful interpretation of the ${ }^{1} \mathrm{H}$, gCOSY, and gHSQC spectra of the 
EtOAc extract allowed assignment of the NMR signals from 4, and these were compared with published data for four synthetic diastereomers of this fatty acid $7 \mathrm{~d}$ including $(2 R, 3 R, 4 R)$-, $(2 S, 3 R, 4 R)-,(2 S, 3 R, 4 S)-$, and $(2 R, 3 R, 4 S)-4 .{ }^{1} \mathrm{H}$ NMR chemical shifts for 4 showed the greatest similarity to those for the $(2 R, 3 R, 4 R)$-isomer, which indicated that the hydroxy acid recovered from the hydrolysis of $\mathbf{1}$ had to have either $(2 R, 3 R, 4 R)$ or $(2 S, 3 S, 4 S)$-stereochemistry. To establish the absolute stereochemistry of these chiral centers, $\mathbf{4}$ from $\mathbf{1}$ was condensed with $(S)-(+)$-phenylglycine methyl ester (PGME) ${ }^{14}$ and the product was subjected to LC-MS analysis. To prepare appropriate chromatographic standards, synthetic $(2 R, 3 R, 4 R)-\mathbf{4}$ was reacted either with $(S)-(+)$ - or (R)-(-)-PGME to obtain $(2 R, 3 R, 4 R)-4(S)-(+)-P G M E$ amide and $(2 R, 3 R, 4 R)-4(R)-(-)-P G M E$ amide. The latter derivative is chromatographically equivalent to the $(S)-(+)$-PGME amide of enantiomeric $(2 S, 3 S, 4 S)-\mathbf{4}$ when chromatographed on an achiral support. The reversed-phase HPLC retention time for the PGME amide prepared from the natural product was identical to that for synthetic $(S)-(+)-P G M E$ amide, thus verifying a $(2 R$, $3 R, 4 R$ ) configuration for the subunit $\mathbf{4}$ in $\mathbf{1}$, which was the same as that established for callipeltin $\mathrm{A}(\mathbf{9}) .7 \mathrm{c}, 7 \mathrm{~d}$

The synthetic procedure we developed to obtain reference standards of the four diastereomers of $\beta \mathrm{OMeTyr}(5)$ was based on the stereoselective synthesis of $\beta$-hydroxytyrosine reported by Boger. ${ }^{15}$ An adaptation of Boger's procedure (Scheme 2), in which a partially diastereoselective addition of a metallated Schöllkopf reagent ${ }^{16}(\mathbf{1 0})$ to 4 benzyloxybenzaldehyde formed the two key stereogenic centers, afforded roughly a 1:1 mixture of two epimeric carbinols (11a,b). Chromatographic separation afforded 11a and 11b in stereochemically pure form. Spectral correlation with Boger's published spectra 15 permitted the assignment of configuration for each isomer. Methylation of the hydroxyl group and hydrolysis of the bis-lactim ether using mild acid afforded stereochemically pure $(S)$ - and $(R)$ - $O$-benzyl-L-tyrosine methyl esters (13a and 13b, respectively). Transesterification with allyl alcohol mediated by titanium tetraisopropoxide afforded the allyl esters $\mathbf{1 4 a}$ and $\mathbf{1 4 b}$ in 15 and $17 \%$ overall yields, respectively, from 4-benzyloxybenzaldehyde. Repetition of this procedure using the enantiomeric Schöllkopf reagent ent-10 afforded ent-14a and ent-14b in stereochemically pure form and in comparable yields. Treatment of the allyl esters 14a, 14b, ent-14a, and ent-14b with $0.2 \mathrm{~N} \mathrm{LiOH}$ and subsequent hydrogenolysis on $\mathrm{Pd}(\mathrm{OH})_{2}$ gave $(S)$ $\beta O M e-L-T y r,(R)-\beta O M e-L-T y r,(R)-\beta O M e-D-T y r$, and $(S)-\beta O M e-D-T y r$, respectively, in quantitative yields.

In a stability test of 5 using the $(S)$ - $\beta$ OMe-D-Tyr as a model, the amino acid tolerated $2 \mathrm{~N} \mathrm{HCl}$ but partially decomposed when kept in $6 \mathrm{~N} \mathrm{HCl}$ for $1.5 \mathrm{~h}$ at room temperature to give a burgundy-colored residue that was insoluble in water but soluble in $\mathrm{MeOH}$. We presumed that acid catalyzed decomposition of the $\beta$ OMeTyr residue might involve elimination of the $\beta$ methoxy group followed by a nucleophilic attack to form condensation products as illustrated in Scheme 3. In an initial effort to avoid decomposition of this residue during hydrolysis, 1 was fully protected with $\mathrm{Cbz}$ and then hydrolyzed in alkaline media, e.g. $1 \mathrm{~N}$ or $2.5 \mathrm{~N} \mathrm{KOH}-$ $\mathrm{MeOH}$, to liberate $N$-Cbz- $\beta \mathrm{OMeTyr}$ or $N, O$-bis(Cbz)- $\beta$ OMeTyr. However, the reaction was inconsistent in yield and detection of the desired products by LC-MS was not successful. Development of an alternative approach to circumvent these problems was clearly warranted. Therefore, the authentic standards of 5 were converted into 3-methoxyaspartic acid (OMeAsp) by oxidation with $\mathrm{RuCl}_{3}-\mathrm{NaIO}_{4}\left(\mathrm{CCl}_{4}-\mathrm{MeCN}-0.1 \mathrm{~N}\right.$ sodium phosphate buffer=2:2:3, $\left.\mathrm{pH} 7.6\right)$, 17 and then isolated as their $N-\mathrm{Cbz}$ derivatives by treating the dried reaction mixtures with $\mathrm{CbzCl}$ followed by solvent-partitioning (Scheme 4). LC-MS analysis of the $\mathrm{N}$-Cbz-OMeAsp products resulted in very broad, low intensity peaks, so the amino acid derivatives were methylated with TMS-diazomethane to give 15. While the peak shape and peak intensity of the dimethyl ester $\mathbf{1 5}$ was improved, it was not possible to resolve the four diastereotopic standards by HPLC, even when they were chromatographed on chiral supports (Regis Sumipax OA-3100 L-Val and Regis Pirkle D-phenylglycine). Successful separation of the four 
diastereomers was ultimately achieved by replacing the Cbz group with TFA (Scheme 4) ${ }^{18}$ and then analyzing the products by GC-MS on a Chirasil-L-Val capillary column. Although a molecular ion for $N$-TFA-OMeAsp dimethyl ester (16) was not observed under the GC-MS conditions, diagnostic fragment ions, e.g. $\mathrm{m} / z 196$ [M- $\cdot \mathrm{COOMe}-\mathrm{MeOH}]^{+}$and $\mathrm{m} / z 103[\mathrm{C}$ $(\mathrm{OMe}) \mathrm{COOMe}]^{+}$(Figure 1), were used to identify each diastereomer which eluted in the order $(2 R, 3 R),(2 S, 3 S),(2 R, 3 S)$, and $(2 S, 3 R)$ with satisfactory peak separation $\left(t_{\mathrm{R}}: 15.5,15.8,16.4\right.$, and $16.7 \mathrm{~min}$, respectively).

With appropriate standards in hand, stereochemical assignments of the $\beta O M e T y r$ residues in 1 and 2 were initiated. The peptides were oxidized with $\mathrm{RuCl}_{3}-\mathrm{NaIO}_{4}$, hydrolyzed in $6 \mathrm{~N} \mathrm{HCl}$ $\left(110^{\circ} \mathrm{C}, 6 \mathrm{~h}\right)$, and the hydrolysates were successively derivatized with $\mathrm{HCl}-\mathrm{MeOH}$ and TFAA to provide GC-MS samples. The extracted ion traces for the $\mathrm{m} / z, 196$ and $\mathrm{m} / z 103$ fragment ions from $N$-TFA-OMeAsp dimethyl ester (16) both clearly showed the elution of ( $2 S$, $3 S)-16\left(t_{\mathrm{R}} 15.8 \mathrm{~min}\right)$ from the oxidative degradation product of $\mathbf{1}$ and $(2 R, 3 S)-\mathbf{1 6}\left(t_{\mathrm{R}} 16.4 \mathrm{~min}\right)$ from that of 2 (Supporting Information). The complete oxidation, hydrolysis, derivatization and analysis sequence was repeated with both parent peptides, and the results were consistent each time. This allowed assignment of a $(R)-\beta \mathrm{OMe}-\mathrm{L}-\mathrm{Tyr}$ residue in $\mathbf{1}$ and a $(R)-\beta \mathrm{OMe}-\mathrm{D}-\mathrm{Tyr}$ residue in 2 .

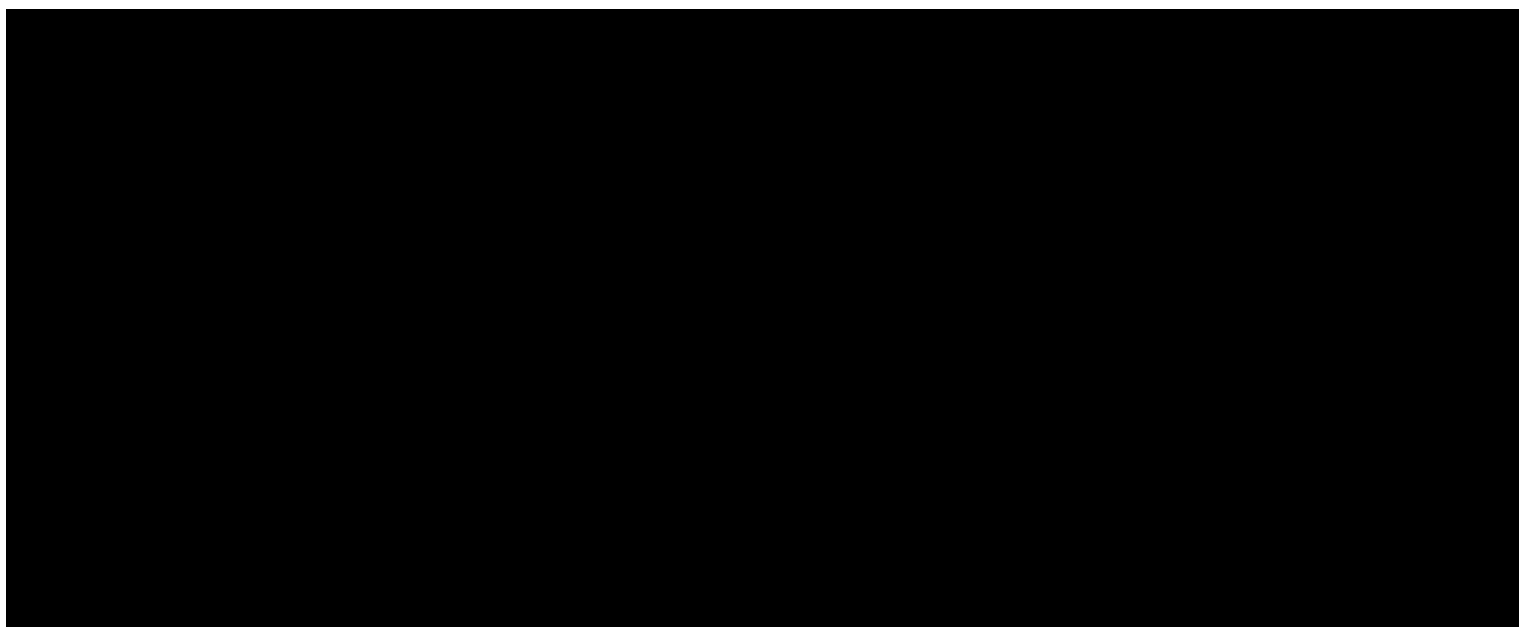

In conclusion, we have defined the absolute configuration of the hydroxy acid moiety and the two unusual amino acid residues in neamphamide $\mathrm{A}(\mathbf{1})$ as $(2 R, 3 R, 4 R)$ - $\mathrm{Htmha},(2 R, 3 R, 4 S)$ Agdha and $(R)-\beta O M e-\mathrm{L}-\mathrm{Tyr}$, respectively. This is the first time the complete stereostructure has been assigned for a member of this family of anti-HIV sponge depsipeptides. In addition, a new analytical procedure was established to determine the absolute configuration of $\beta O M e T y r$ residues in peptide natural products. Application of this technique to papuamide B (2) revealed the presence of $(R)-\beta O M e-D-T y r$ in 2 , which is epimeric at $\mathrm{C} \alpha$ to the corresponding residue in $\mathbf{1}$. The stereochemical divergence of the $\beta O M e T y r$ residues in $\mathbf{1}$ and $\mathbf{2}$ is somewhat surprising considering the structural similarities and comparable inhibitory activity against HIV for these two peptides. However, this finding is consistent with the observation that the $\beta O M e T y r ~ C \beta$ proton in $\mathbf{1}$ is a broadened singlet at $\delta 5.03$ while the same proton in $\mathbf{2}$ appears as a $9.3 \mathrm{~Hz}$ doublet at $\delta 4.24$. The differing stereochemistry at $\mathrm{C} \alpha$ suggests that during biosynthesis of $\mathbf{1}$ and $\mathbf{2}$ the $\beta O M e T y r$ residues arise from incorporation of L-Tyr and D-Tyr, respectively, while the oxidative modification at $\mathrm{C} \beta$ occurs with conserved stereochemistry regardless of the configuration at $\mathrm{C} \alpha$. Assignment of the complete absolute stereochemistry of neamphamide A (1) and the $\beta O M e T y r$ residue in papuamide B (2) should now simplify the efforts required to synthesize these peptides. In addition, the method developed for analyzing the $\beta \mathrm{OMeTyr}$ 
residues should be applicable to other naturally occurring peptides that contain this amino acid derivative.

\section{Experimental Section}

GC-MS analysis. Chiral GC-MS analyses were executed with an Agilent 6890 Series/5973N gas chromatograph-mass selective detector system equipped with a Varian Chirasil-L-Val capillary column $(25 \mathrm{~m} \times 0.25 \mathrm{~mm}$ i.d., $0.16 \mu \mathrm{m}$ film thickness $)$, using helium as a carrier gas at a linear velocity of $29.2 \mathrm{~cm} / \mathrm{s}$. Temperatures were set to $250{ }^{\circ} \mathrm{C}$ at the injection port and 220 ${ }^{\circ} \mathrm{C}$ at the transfer line to the detector. Samples were injected splitless and chromatographed under the oven temperature program of $60^{\circ} \mathrm{C}$ for $3 \mathrm{~min}, 5^{\circ} \mathrm{C} / \mathrm{min}$ heat ramp to $200{ }^{\circ} \mathrm{C}$, and the same temperature held for $10 \mathrm{~min}$. Electron-impact ionization at $70 \mathrm{eV}$ was employed for mass spectral detection and elution of $N$-TFA-OMeAsp dimethyl ester (16) was traced by diagnostic fragment ions at $m / z 196$ and $m / z 103$.

Conversion of $\beta O M e T y r(5)$ into $N$-TFA-OMeAsp Dimethyl Ester (16). A solution of each deprotected amino acid standard $(100 \mu \mathrm{g})$ in a mixture of $\mathrm{MeCN}(40 \mu \mathrm{L})$ and $\mathrm{H}_{2} \mathrm{O}(30 \mu \mathrm{L})$ was stirred with $\mathrm{NaIO}_{4}(2.4 \mathrm{mg})$ until the salt crystals disappeared. To this solution was added $\mathrm{CCl}_{4}\left(40 \mu \mathrm{L}\right.$ ) and a $1 \mathrm{mg} / \mathrm{mL}$ solution of $\mathrm{RuCl}_{3}$ hydrate in $0.1 \mathrm{~N}$ sodium phosphate buffer (30 $\mu \mathrm{L}, \mathrm{pH}$ 7.6) and the biphasic mixture was vigorously stirred at room temperature for $16 \mathrm{~h}$. After removal of the solvent, a half portion of the oxidation product was reacted with $\mathrm{CbzCl}(20$ $\mu \mathrm{L})$ in a mixture of $1 \mathrm{~N} \mathrm{KOH}(50 \mu \mathrm{L})$ and freshly distilled 1,4-dioxane $(50 \mu \mathrm{L})$. After stirring for an hour at ambient temperature, $100 \mu \mathrm{L}$ of $1 \mathrm{~N} \mathrm{KOH}$ was added to the reaction mixture and the unreacted reagent was extracted with EtOAc $(100 \mu \mathrm{L} \times 3)$. The aqueous layer was then acidified with $2 \mathrm{~N} \mathrm{HCl}(150 \mu \mathrm{L})$ and extracted again with EtOAc $(100 \mu \mathrm{L} \times 5)$, which yielded $\mathrm{N}$-Cbz-OMeAsp. This material was further esterified with TMS-diazomethane $(10 \mu \mathrm{L}, 2 \mathrm{M}$ solution in $n$-hexane) in $\mathrm{MeOH}(50 \mu \mathrm{L})$ by stirring the reaction mixture for $1 \mathrm{~h}$ to give $\mathrm{N}$-CbzOMeAsp dimethyl ester (15), followed by deprotection of the $\mathrm{N}$-Cbz group by hydrogenolysis on $20 \% \mathrm{Pd}(\mathrm{OH})_{2}$ on carbon ( $1 \mathrm{mg}$ suspension in $100 \mu \mathrm{L} \mathrm{4.4 \%} \mathrm{HCOOH}$ in $\mathrm{MeOH}$ ) under a $\mathrm{H}_{2}$ atmosphere at room temperature for $4 \mathrm{~h}$. The glass-wool filtrate of the reaction suspension was concentrated and again methylated with $1.25 \mathrm{M} \mathrm{HCl}$ in $\mathrm{MeOH}(100 \mu \mathrm{L})$ at $110^{\circ} \mathrm{C}$ for 20 min, followed by TFA-amidation with dichloromethane/TFA anhydride $(1: 1,100 \mu \mathrm{L})$ at the same temperature for $5 \mathrm{~min}$ to give $N$-TFA- OMeAsp dimethyl ester (16). The derivatization product was dissolved in MeCN $(15 \mu \mathrm{L})$ and a $1 \mu \mathrm{L}$ aliquot was subjected to GC-MS analysis. Retention times (min): 15.5 for $(2 R, 3 R)-, 15.8$ for $(2 S, 3 S)$-, 16.4 for $(2 R, 3 S)$-, and 16.7 for $(2 S, 3 R)-16$.

Analysis of the BOMeTyr Residues in Neamphamide A (1) and Papuamide B (2). A 200$\mu \mathrm{g}$ portion of each peptide was oxidized with $\mathrm{RuCl}_{3} / \mathrm{NaIO}_{4}$ as described in the previous section. The dried reaction mixture was dissolved in $1 \% \mathrm{MeOH}$ in $\mathrm{H}_{2} \mathrm{O}$, applied to a short column of reversed-phase polymer (PolysorbTM MP-1, $100 \mathrm{mg}$ ), and desalted by washing with the same alcoholic water mixture. The peptide was recovered from the column by elution with $\mathrm{MeOH}$ and then hydrolyzed in degassed $6 \mathrm{~N} \mathrm{HCl}(200 \mu \mathrm{L})$ at $110^{\circ} \mathrm{C}$ for $6 \mathrm{~h}$. Half of the hydrolysate was derivatized with $\mathrm{HCl}-\mathrm{MeOH}$ followed by dichloromethane/TFA anhydride as described above, and a $1 \mu \mathrm{L}$ aliquot of the product dissolved in $\mathrm{MeCN}(33 \mu \mathrm{L})$ was subjected to GC-MS analysis. Retention times (min): 15.8 for $N$-TFA-OMeAsp dimethyl ester (16) from $\mathbf{1}$ and 16.4 for $\mathbf{1 6}$ from 2.

\section{Supplementary Material}

Refer to Web version on PubMed Central for supplementary material. 


\section{Acknowledgements}

ACKNOWLEDGMENT. We thank Prof. M. V. D'Auria at Univ. Napoli "Federico II" for helpful discussions. M. A. L. gratefully acknowledges the financial support of the National Institutes of Health (AI-50888). The content of this publication does not necessarily reflect the views or policies of the Department of Health and Human Services, nor does mention of trade names, commercial products, or organizations imply endorsement by the U.S. government.

\section{References and Notes}

(1). Oku N, Gustafson KR, Cartner LK, Wilson JA, Shigematsu N, Hess S, Pannell LK, Boyd MR, McMahon JB. J. Nat. Prod 2004;67:1407-1411. [PubMed: 15332865]

(2). (a) Zampella A, D'Auria MV, Paloma LG, Casapullo A, Minale L, Debitus C, Henin Y. J. Am. Chem. Soc 1996;118:6202-6209. (b) D'Auria MV, Zampella A, Paloma LG, Minale L, Debitus C, Roussakis C, Le Bert V. Tetrahedron 1996;52:9589-9596. (c) Zampella A, Randazzo A, Borbone N, Luciani S, Trevisi L, Debitus C, D’Auria MV. Tetrahedron Lett 2002;43:6163-6166.

(3). Ford PW, Gustafson KR, McKee TC, Shigematsu N, Maurizi LK, Pannell LK, Williams DE, de Silva ED, Lassota P, Allen TM, Van Soest R, Andersen RJ, Boyd MR. J. Am. Chem. Soc 1999;121:5899_ 5909.

(4). Trevisi L, Bova S, Cargnelli G, Danieli-Betto D, Floreani M, Germinario E, D’Auria MV, Luciani S. Biochem. Biophys. Res. Comm 2000;279:219-222. [PubMed: 11112442] (b) Trevisi L, Cargnelli G, Ceolotto G, Papparella I, Semplicini A, Zampella A, D’Auria MV, Luciani S. Biochem. Pharmacol 2004;68:1331-1338. [PubMed: 15345322]

(5). (a) Liang B, Carroll PJ, Joullie MM. Org. Lett 2000;2:4157-4160. [PubMed: 11150188] (b) Okamoto N, Hara O, Makino K, Hamada Y. Tetrahedron: Asymmetry 2001;12:1353-1358. (c) Acevedo CM, Kogut EF, Lipton MA. Tetrahedron 2001;57:6353-6359. [PubMed: 18159221]

(6). Thoen JC, Morales-Ramos ÁI, Lipton MA. Org. Lett 2002;4:4455-4458. [PubMed: 12465911]

(7). (a) Guerlavais V, Carroll PJ, Joullie MM. Tetrahedron: Asymmetry 2002;13:675-680. (b) Zampella A, Sorgente M, D’Auria MV. Tetrahedron: Asymmetry 2002;13:681-685. (c) Zampella A, D'Auria MV. Tetrahedron: Asymmetry 2002;13:1237-1239. (d) Turk JA, Visbal GS, Lipton MA. J. Org. Chem 2003;68:7841-7844. [PubMed: 14510564]

(8). (a) Okamoto N, Hara O, Makino K, Hamada Y. J. Org. Chem 2002;67:9210-9215. [PubMed: 12492322] (b) Hansen DB, Wan X, Carroll PJ, Joullie MM. J. Org. Chem 2005;70:3120. [PubMed: 15822973]

(9). Marphy P. Carlsberg Res. Comm 1984;49:591-596.

(10). In ref.1(a), the authors reported a molecular ion of Agdha at m/z 252 and attributed the increase of $17 \mathrm{mu}$ to the formation of an $\mathrm{NH}_{3}$ adduct. Although it was not mentioned if $\mathrm{CD}_{3} \mathrm{OD}$ was used in NMR experiments prior to the mass measurement, it is possible that the mass observed was the molecular ion of 16 .

(11). Meyers AI, Lawson JP. Tetrahedron Lett 1982;23:4883-4886.

(12). Hardy PM. Synthesis 1978:290-291.

(13). Huang Y, Dalton D, Carroll PJ. J. Org. Chem 1997;62:372-376. [PubMed: 11671412]

(14). Nagai N, Kusumi T. Tetrahedron Lett 1995;36:1853-1856.

(15). Boger DL, Zhou J, Borzilleri RM, Nukui S, Castle SL. J. Org. Chem 1997;62:2054-2069. [PubMed: 11671510]

(16). Schöllkopf U, Groth U, Deng C. Angew. Chem. Int. Ed 1981;20:798-799.

(17). Oxidation without using a buffered solution did not give OMeAsp.

(18). In a preliminary GC-MS experiment using D- and L- $N$-Cbz-Asp dimethyl esters as the models, both compounds eluted approximately 5 min after the thermal gradient reached the maximum temperature limit of the Chirasil column $\left(200^{\circ} \mathrm{C}\right)$ with poor mutual separation. This suggested that other derivatization of the amino group instead of $\mathrm{Cbz}$ was required to improve the chromatographic 
behavior of the methylated OMeAsp derivatives. 
Chart 1.

Structure of neamphamide A (1), papuamide B (2), Agdha (3), Htmha (4), and ßOMeTyr (5). 
Scheme 1.

aReagents and conditions: (a) $6 \mathrm{~N} \mathrm{HCl}, 107^{\circ} \mathrm{C}, 18.5 \mathrm{~h}$; (b) solvent partitioning, $6 \mathrm{~N} \mathrm{HCl} / \mathrm{EtOAc}$; (c) $\mathrm{CD}_{3} \mathrm{OD}, 65 \mathrm{~h}$; (d) PPTS, 2,2-dimethoxypropane, DMF, $45^{\circ} \mathrm{C}(30 \mathrm{~min})->60^{\circ} \mathrm{C}(1.5 \mathrm{~h})$; (e) $2 \mathrm{~N} \mathrm{HCl}$ in $\mathrm{MeOH}, 60{ }^{\circ} \mathrm{C}, 15.5 \mathrm{~h}$; (f) $\mathrm{H} \mathrm{O}$, reflux, $60 \mathrm{~h} .{ }^{b}$ bata reproduced from ref. 55. 
Chart 2.

Structure of callipeltin A (9). 
Scheme 2.

aReagents and conditions: (a) BuLi, 4-BnPhCHO, THF, $-30{ }^{\circ} \mathrm{C}, 3 \mathrm{~h}$; (b) NaI, $\mathrm{CH}_{3} \mathrm{I}, \mathrm{THF}, 0^{\circ}$ $\mathrm{C}, 3 \mathrm{~h}$; (c) $0.25 \mathrm{~N} \mathrm{HCl}$, THF-MeCN, $25^{\circ} \mathrm{C}, 16 \mathrm{~h}$; (d) Ti(Oi-Pr) ${ }_{4}$, allyl alcohol, $25^{\circ} \mathrm{C}, 24 \mathrm{~h}$; (e) $0.2 \mathrm{~N} \mathrm{LiOH}-\mathrm{MeOH}, \mathrm{rt}, 2$ days; (f) $\mathrm{H}_{2}, \mathrm{Pd}(\mathrm{OH})_{2} / \mathrm{C}, \mathrm{MeOH}-4.4 \% \mathrm{HCOOH}, \mathrm{rt}, 4 \mathrm{~h}$. 


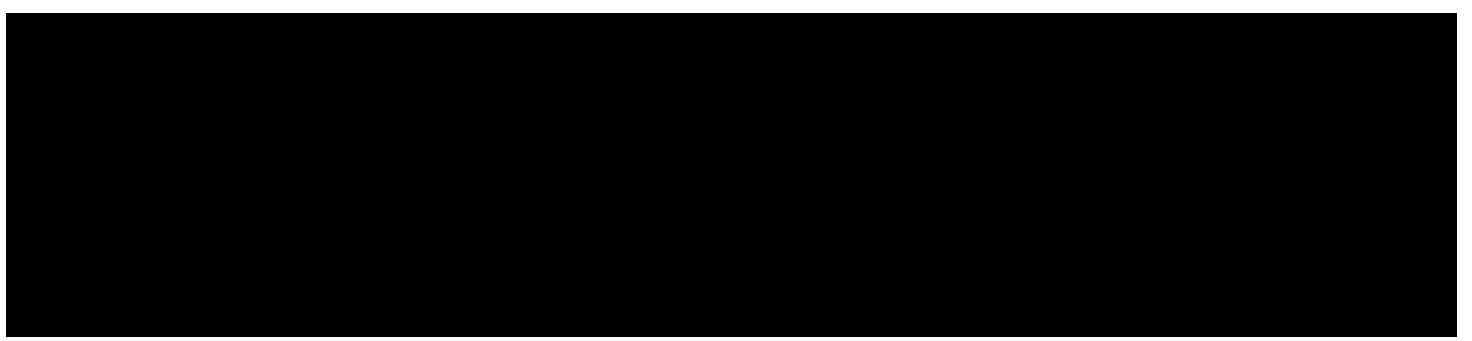

Scheme 3. 


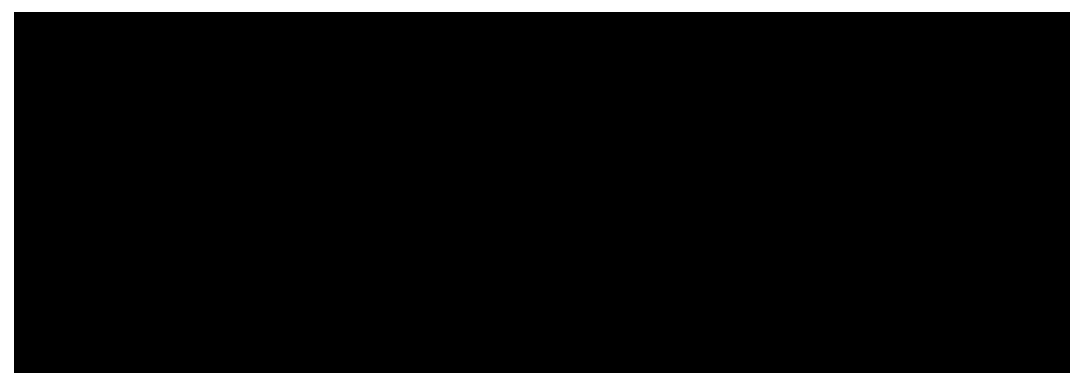

Scheme 4.

aReagents and conditions: (a) $\mathrm{RuCl}_{3}, \mathrm{NaIO}_{4}, \mathrm{CCl}_{4}-\mathrm{MeCN}-0.1 \mathrm{M}$ sodium phosphate buffer=2:2:3, pH 7.6, rt, $16 \mathrm{~h}$; (b) CbzCl, 1,4-dioxane-1 N KOH, rt, 1h; (c) TMS-diazomethane, $\mathrm{MeOH}, \mathrm{rt}, 1 \mathrm{~h}$; (d) $\mathrm{Pd}(\mathrm{OH})_{2}, 4.4 \% \mathrm{HCOOH}$ in $\mathrm{MeOH}, \mathrm{H}_{2}$, rt, 4 h; (e) $1.25 \mathrm{M} \mathrm{HCl}$ in $\mathrm{MeOH}$, $110^{\circ} \mathrm{C}, 30 \mathrm{~min}$; (f) TFAA, dichloromethane, $110^{\circ} \mathrm{C}, 5 \mathrm{~min}$. 


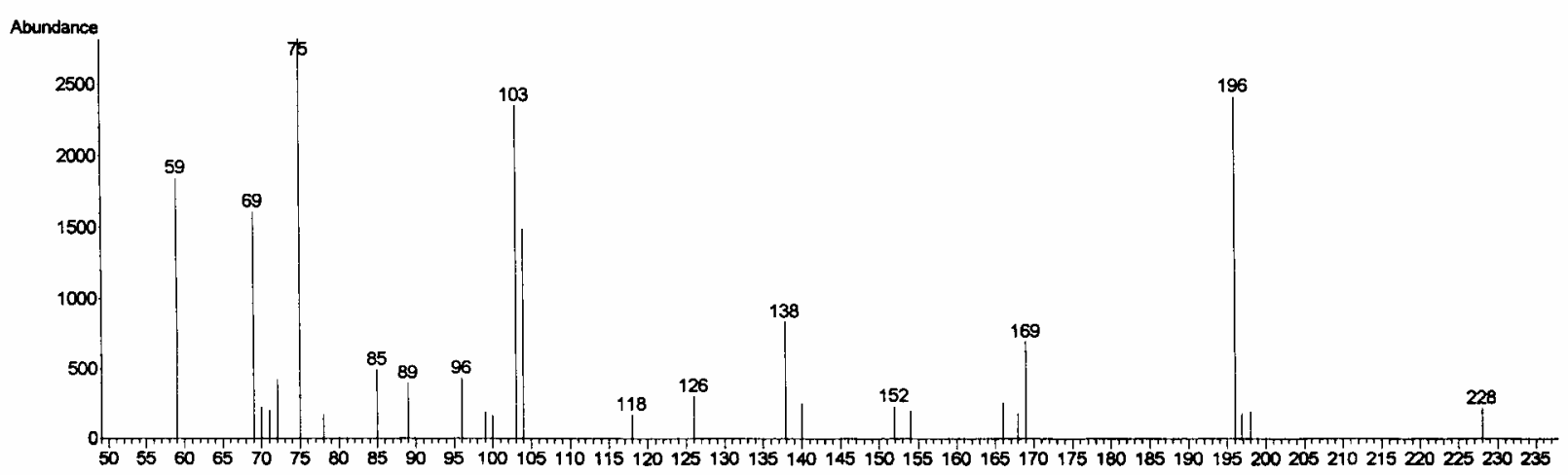

Figure 1.

Fragmentation and the typical EI-MS spectrum of $N$-TFA-OMeAsp dimethyl ester (16). 